\title{
Detection of aerobe-anaerobe mixed infection by metagenomic next-generation sequencing in an adult suffering from descending necrotizing mediastinitis
}

\author{
Jing Duan ${ }^{1}$, Chuncheng Zhang ${ }^{2}$, Xiaoshuang Che ${ }^{3}$, Juanjuan Fu ${ }^{1}$, Feng Pang ${ }^{1}$, Qigang Zhao ${ }^{1}$ and \\ Zhiqing You ${ }^{1 *}$ (1)
}

\begin{abstract}
Background: Descending necrotizing mediastinitis (DNM) is one of the most virulent forms of mediastinitis. The main causes of high mortality in DNM are believed to stem from difficulty and delay in the diagnosis. Fast and accurate identification of pathogens is important for the treatment of these patients. Metagenomics next-generation sequencing (mNGS) is a powerful tool to identify all kinds of pathogens, especially for rare and complex infections.

Case presentation: A 64-year-old male patient was admitted to the intensive care unit (ICU) with unconsciousness, dyspnea, and swelling in the mandible and neck. Computed tomography (CT) scan results combined with clinical laboratory examination indicated DNM. Vancomycin and imipenem were used, and vacuum sealing drainage was applied for debridement and drainage of the infected area. The positive mNGS results of drainage fluid confirmed the presence of mixed infection caused by Streptococcus anginosus, Prevotella oris, and several other anaerobes. The antibiotics were adjusted to piperacillin/tazobactam and tinidazole according to the mNGS results and antimicrobial susceptibility testing of cultured pathogens. After 11 days of antibiotic therapy, the infection symptoms of the neck and mediastinum improved, and the patient was transferred out of the ICU on the $26^{\text {th }}$ day after negative result of drainage fluid culture.
\end{abstract}

Conclusion: This case suggested that mNGS is a promising technology for precise and fast pathogens identification with high sensitivity, which may guide the diagnosis of infectious diseases in the future trend.

Keywords: Descending necrotizing mediastinitis, mNGS, Aerobe-anaerobe mixed infection

\section{Background}

Descending necrotizing mediastinitis (DNM) is a type of pyogenic mediastinitis, the infections usually have a fulminant course leading to sepsis and even death. Dental infection is a common cause of DNM, followed by

\footnotetext{
*Correspondence: txt19876@163.com

${ }^{1}$ Department of Clinical Laboratory, Liaocheng People's Hospital, No. 67, Dongchangxi Road, Dongchangfu District, Liaocheng 252000, Shandong, People's Republic of China

Full list of author information is available at the end of the article
}

retropharyngeal abscesses, peritonsillar abscesses, traumatic endotracheal intubation, trauma, cervical lymphadenitis, and osteomyelitis. Criteria for diagnosis of DNM are: (1) clinical manifestations of oropharyngeal infection; (2) characteristic roentgenographic features of mediastinitis; (3) documentation of mediastinitis during surgery or postmortem examination; (4) establishment of a relationship between oropharyngeal infection and subsequent necrotizing mediastinitis [1].The mortality of DNM has been reported to be $40 \%$, which is 
approximately treble the risk of septic shock $[2,3]$. However, prompt diagnosis, early aggressive incision, sufficient drainage, targeted antibiotic therapy combined with intensive care unit (ICU) management could significantly reduce the mortality to less than $20 \%$ [4]. Herein, we report a case in which mNGS was applied to identify the pathogens of DNM caused by odontogenic infection.

\section{Case presentation}

A 61-year-old male patient with a history of hypertension was admitted to the ICU, with loss of consciousness and dyspnea. He had a toothache 15 days ago, and got some non-steroidal anti-inflammatory drugs in local pharmacy. However, the condition was not improved and mandible and neck begun to swell 10 days ago, and the situation deteriorated in the following days until he was admitted. The patient's vitals were as follows: radial artery blood pressure was 112/77 $\mathrm{mmHg}$, axillary temperature was $36.8^{\circ} \mathrm{C}$, heart rate was $90 \mathrm{bpm}$, oxygen concentration was $45 \%$ with high flow oxygen inhalation, and blood oxygen saturation was 99\%. Lung breath was clear, with no audible dry or wet rales. Blood test results: the leukocyte count was $4.05 \times 10^{9} / \mathrm{L}$ with high percentage of neutrophils and low percentage of lymphocyte ( $90.4 \%$ and $4.3 \%$, respectively), C-reactive protein (CRP) was $>200 \mathrm{mg} / \mathrm{L}$, and procalcitonin (PCT) was $9.32 \mathrm{ng} /$ $\mathrm{ml}$ (Table 1). CT scan showed gas-like images in the left submandibular tissues and neck, cervical lymph node enlargement, obvious pleural effusion, and normal lungs (Fig. 1A-D). Clinical examinations and CT results indicated the presence of infection with aerogenic bacteria.

On the first day of hospitalization, the patient's blood oxygen saturation dropped to $80 \%$, he was treated with tracheal intubation and mechanical ventilation, vacuum sealing drainage (VSD) was also applied for the debridement and drainage of the infected area. Symptomatic treatment was also conducted, such as nutritional support and maintenance of water-electrolyte balance. Vancomycin (VAN) was treated for suspected gram-positive cocci infection. On the second day of hospitalization,
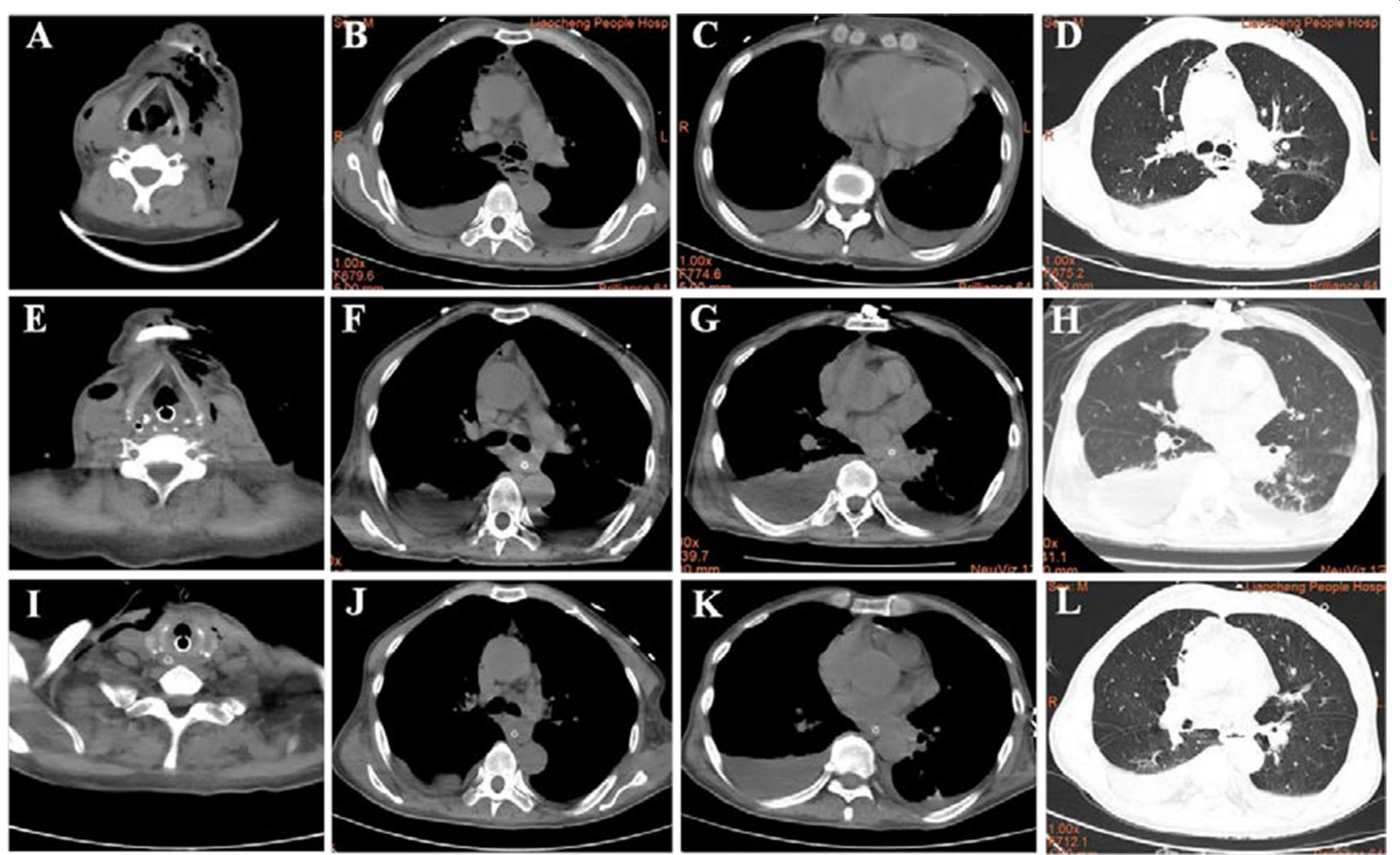

Fig. 1 CT images of the patient atday 0 , day 5 and day 11 of hospitalization.A-D The CT images of thepatient at the time of admission, the mandibular space and mediastinum of thepatient has obvious gas shadow, there is pleural effusion, and the lung imageis normal; $\mathbf{E}-\mathbf{H} T$ The $C T$ images of the patient 5 days after admission andtreatment, the mandibular space and mediastinal gas after drainage treatment reduced,but the infection of the neck and mediastinum did not change significantly, theamount of pleural effusion increased compared with previous, and the lungs appeared asstrips of increased density which indicating lung infection; I-LThe CT images of the patient 11 days after admission, the submandibular space andmediastinal gas decreased, neck and mediastinal infections improved, lunginfections improved, and pleural effusion decreased 
Table 1 Physical examination and laboratory test during the period of hospitalization

\begin{tabular}{|c|c|c|c|c|c|}
\hline & Indexes & Day 0 & Day 5 & Day 11 & Day 20 \\
\hline Physical examination & $\begin{array}{l}\text { Axillary temperature: } \\
\text { oxygen saturation: } \\
\text { blood pressure: } \\
\text { Status of affected area }\end{array}$ & $\begin{array}{l}36.8{ }^{\circ} \mathrm{C} \\
99 \% \\
112 / 77 \mathrm{mmHg} \\
\text { red and swollen }\end{array}$ & $\begin{array}{l}37.3{ }^{\circ} \mathrm{C} \\
100 \% \\
135 / 72 \mathrm{mmHg} \\
\text { red and swollen }\end{array}$ & $\begin{array}{l}36.5{ }^{\circ} \mathrm{C} \\
100 \% \\
128 / 65 \mathrm{mmHg} \\
\text { red and swollen }\end{array}$ & $\begin{array}{l}36.7^{\circ} \mathrm{C} \\
98 \% \\
114 / 68 \mathrm{mmHg} \\
\text { swollen Improved }\end{array}$ \\
\hline Laboratory test & $\begin{array}{l}\text { WBC: }(3.5-9.5) \times 10^{9} / \mathrm{L} \\
\text { Neutrophil\%: }(40-75) \% \\
\text { CRP: }(0-10) \mathrm{mg} / \mathrm{L} \\
\text { PCT: }(0-0.5) \mathrm{ng} / \mathrm{L} \\
\text { IL-6: } \leq 5.4 \mathrm{pg} / \mathrm{ml} \\
\text { IL-10: } \leq 12.9 \mathrm{pg} / \mathrm{ml}\end{array}$ & $\begin{array}{l}4.05 \times 10^{9} / \mathrm{L} \\
90.4 \% \\
>200 \mathrm{mg} / \mathrm{L} \\
9.32 \mathrm{ng} / \mathrm{ml} \\
387.06 \mathrm{pg} / \mathrm{ml} \\
69.19 \mathrm{pg} / \mathrm{m}\end{array}$ & $\begin{array}{l}5.77 \times 10^{9} / \mathrm{L} \\
87 \% \\
>200 \mathrm{mg} / \mathrm{L} \\
9.77 \mathrm{ng} / \mathrm{ml} \\
330.04 \mathrm{pg} / \mathrm{ml} \\
50.82 \mathrm{pg} / \mathrm{m}\end{array}$ & $\begin{array}{l}4.61 \times 10^{9} / \mathrm{L} \\
69.4 \\
19.79 \mathrm{mg} / \mathrm{L} \\
1.06 \mathrm{ng} / \mathrm{ml} \\
153.56 \mathrm{pg} / \mathrm{ml} \\
34.42 \mathrm{pg} / \mathrm{m}\end{array}$ & $\begin{array}{l}7.53 \times 10^{9} / \mathrm{L} \\
70.5 \\
\text { NA } \\
\text { NA } \\
60.22 \mathrm{pg} / \mathrm{ml} \\
26.72 \mathrm{pg} / \mathrm{ml}\end{array}$ \\
\hline
\end{tabular}

the inflammatory indexes were still high with wet rales in both lungs. Therefore, imipenem (IPM) was administered to treat gram-negative bacteria infection. However, on the third hospital day the temperature rose to $38.3^{\circ} \mathrm{C}$, indomethacin suppository was administered rectally to bring down a fever. Drainage fluid from the lesions and blood were drawn to culture for microbes, an aliquot of the drainage fluid was also sent to the clinical laboratory for mNGS. On the $5^{\text {th }}$ day of hospitalization, the patient's temperature returned to normal, but the percentage of neutrophils, CRP, and PCT levels were still high $(87 \%,>200 \mathrm{mg} / \mathrm{L}, 9.77 \mathrm{ng} / \mathrm{mL}$, respectively). A second CT scan showed that the gas content in the tissues and extent of neck inflammation were reduced, but inflammatory lesions had appeared in the lungs, with increased bilateral pleural effusion volume (Fig. 1E-H). The result of mNGS revealed mixed infection by Streptococcus anginous, Prevotella oris, Prevotella denticola, Peptostreptococcus stomatis, Fusobacterium nucleatum, and Alloprevotella tannerae (Table 2). Thus, the antibiotic therapy was adjusted to piperacillin/tazobactam (TZP) and tinidazole (TNZ) based on positive results of mNGS.

On the $6^{\text {th }}$ day of hospital stay, Streptococcus anginous was retrieved by culture of the drainage fluid, without any anaerobic bacteria detected. The isolated strain was sensitive to TZP (Table 3) according to antimicrobial susceptibility testing (AST) results. Hence, TZP and TNZ were continued for the treatment. The interpretive criterion of AST was established according to the latest edition of performance standards for antimicrobial susceptibility testing updated by the Clinical and Laboratory Standards Institute. Bronchoalveolar lavage was performed through fiberoptic bronchoscopy to remove secretions of respiratory, and bronchoalveolar lavage fluid (BALF) was sent to the microbiology laboratory for culture. On the 7th day of hospital stay, ultrasoundguided thoracic puncture was performed to drain pleural effusion fluids. On the 8th day of hospital stay, A methicillin-resistant coagulase-negative (MRSCN) Staphylococcus hominis strain was identified by blood cultures, and VAN was added to the antibiotic regiments according to the AST result (Table 3). On the 9th day a strain of Pseudomonas aeruginosa which sensitive to TZP was recovered from BALF by culture, thus change in antibiotics was not necessary (Fig. 2, Table 3). The patient's general condition was improved and the mechanical ventilation was switched to high-flow oxygen inhalation. On the 11th day of hospital stay, the percentage of neutrophils returned to normal, CRP and PCT levels were significantly lower than before, indicating reduction of the infection. A third CT scan showed that the gas content in the inferior space and mediastinum cavity decreased, the infection symptoms of the neck and mediastinum relieved, the lung infection decreased, and the amount of pleural effusion was less extensively than before (Fig. 1IL). Based on the patient's improved clinical conditions

Table 2 Pathogens recovered by mNGS in drainage fluid

\begin{tabular}{|c|c|c|c|c|c|}
\hline Genus & Reads no. & $\begin{array}{l}\text { Genus relative } \\
\text { abundance }\end{array}$ & Species & Reads no. & $\begin{array}{l}\text { Species relative } \\
\text { abundance (\%) }\end{array}$ \\
\hline \multirow[t]{2}{*}{ Prevotella } & 202,442 & $48.59 \%$ & Prevotella oris & 78,656 & 18.32 \\
\hline & & & Prevotella denticola & 27,149 & 8.53 \\
\hline Streptococcus & 53,838 & $20.19 \%$ & Streptococcus anginosus & 28,322 & 18.29 \\
\hline Peptostreptococcus & 22,052 & $8.22 \%$ & Peptostreptococcus stomatis & 21,470 & 8.09 \\
\hline Fusobacterium & 11,837 & $4.53 \%$ & Fusobacterium nucleatum & 6789 & 3.67 \\
\hline Alloprevotella & 11,472 & $3.63 \%$ & Alloprevotella tannerae & 11,347 & 3.58 \\
\hline
\end{tabular}




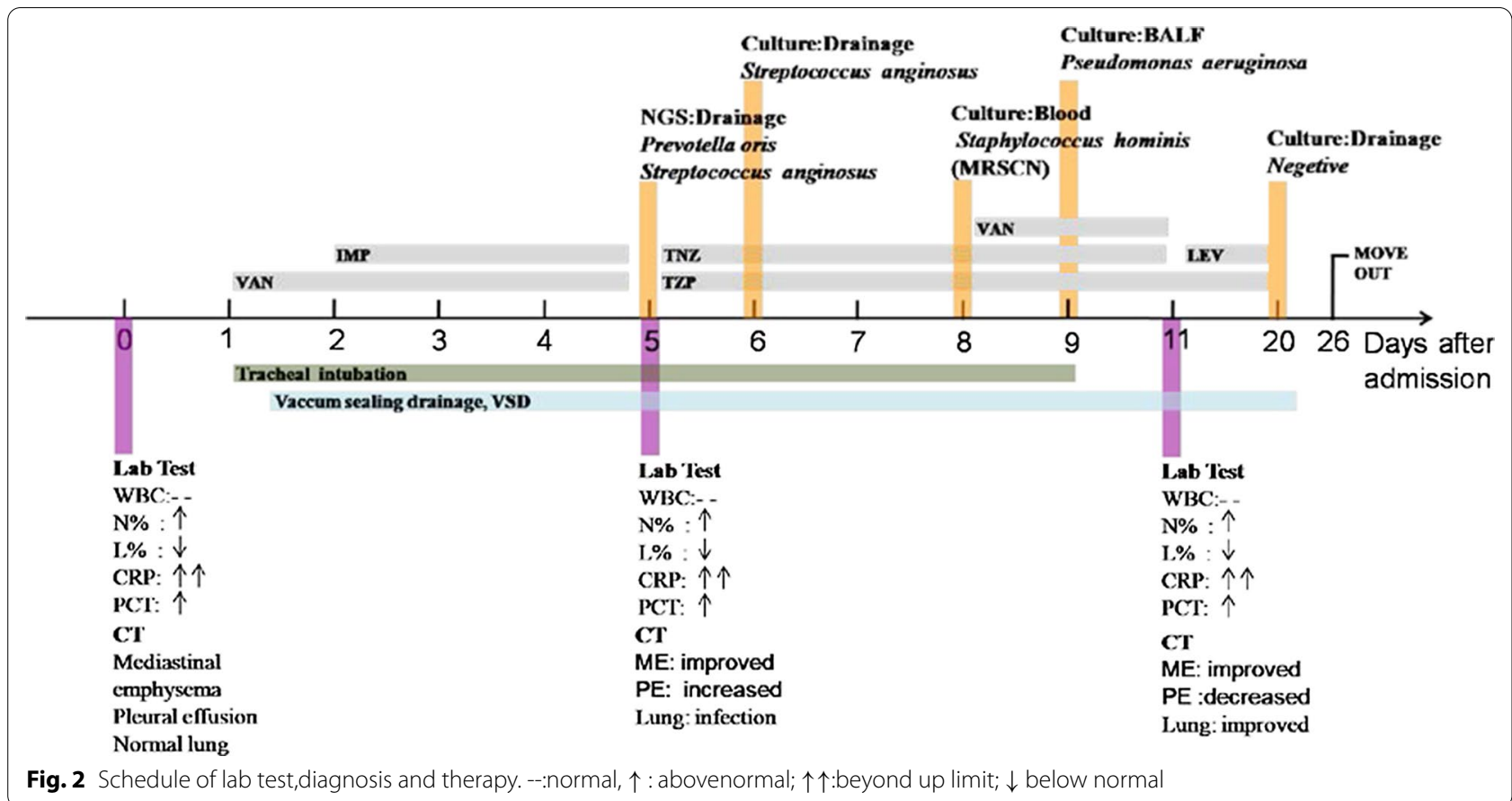

and previous AST results, the antibiotic treatment was changed to Levaquin (LEV) and TZP. The patient was discharged out of ICU after obtaining a negative result of the drainage fluid bacterial culture (Fig. 2).

\section{Discussion and conclusion}

Acute purulent mediastinitis is a fatal condition which occurs after an esophageal perforation or that develops as a complication of odontogenic infection[5]. Infections in the posterior lower teeth are more likely to progress to DNM due to their drainage into the submandibular space, located near the retropharyngeal and lateral pharyngeal spaces[6]. Infection of the oropharyngeal cavity can rapidly spread along the fascial planes into the mediastinum space, where DNM develops. Because of the high lethality and rapid progression of DNM, prompt diagnosis, appropriate and adequate surgical drainage, in addition to supportive antibiotic therapy, combined with intensive medical care, are determinants for the success of the treatment and recovery [4]. CT reportedly contributes to early diagnosis of mediastinitis, owing to the capability of identifying the presence and extension of the disease, providing accurate information about the location and extent of the infection, guiding the management approach, and monitoring the drainage process $[7,8]$. CT plays an important role in the diagnosis and assessment of therapeutic effectiveness. Another important factor that affects the clinical outcome of the patient is the type of microorganism that leading to the infection. As previously reported, DNM often comes from polymicrobial infection, and the most frequent microorganisms isolated are of the genus Streptococcus as well as anaerobic microbial bacteria of the genera Prevotella, Peptostreptococcus, Bacteroides, and Fusobacterium. Other pathogens isolated from DNM patients including bacteria belonging to the genera Staphylococcus, Pesudomonas, Escherichia, Enterobacter, Acinetobacter, Enterococcus, etc. $[9,10]$. As reported in a literature review, a total of 156 microorganisms were isolated from 55 patients $(61.8 \%)$, no pathogens can be isolated in approximately $40 \%$ of the cases of DNM [11]. The reason for this may be the complexity of the microorganisms and limitations of traditional microbial detection methods, such as morphological detection, culture, biochemical detection, and serotyping. These methods can only identify one or several specific pathogens, but cannot identify unknown or rare pathogenic microorganisms.

mNGS is a versatile technology which can identify pathogens more rapidly and precisely than traditional methods, and can even provide new insights into disease transmission, virulence, and antimicrobial resistance. Compared to traditional detection methods which can only detect certain targeted pathogens, mNGS is a shotgun sequencing method of RNA and DNA from clinical samples, where all DNA or RNA of the sample to be tested are mixed and sequenced, and the data is then compared with the pathogen database to obtain classification information of the pathogens. This method can 
Table 3 Antimicrobial susceptibility testing results of cultured pathogens

\begin{tabular}{|c|c|c|c|c|c|c|c|}
\hline \multirow[t]{2}{*}{ Pathogen } & \multirow{2}{*}{$\begin{array}{l}\text { Antimicrobial } \\
\text { agent }\end{array}$} & \multirow[t]{2}{*}{ Method (unit) } & \multicolumn{3}{|c|}{ Interpretive standard } & \multirow[b]{2}{*}{ Result } & \multirow[b]{2}{*}{ Sensitivity } \\
\hline & & & $\mathrm{S}$ & 1 & $\mathbf{R}$ & & \\
\hline \multirow{10}{*}{$\begin{array}{c}\text { Streptococcus } \\
\text { anginosus }\end{array}$} & Penicillin & $\mathrm{MIC}(\mathrm{ug} / \mathrm{ml})$ & $\leq 0.12$ & $0.25-2$ & $\geq 4$ & 0.064 & s \\
\hline & Linezolid & $\mathrm{KB}(\mathrm{mm})$ & $\geq 21$ & NA & NA & 28 & S \\
\hline & Levofloxacin & $\mathrm{KB}(\mathrm{mm})$ & $\geq 17$ & $14-16$ & $\leq 13$ & 28 & S \\
\hline & Ceftriaxone & $\mathrm{KB}(\mathrm{mm})$ & $\geq 27$ & $25-26$ & $\leq 24$ & 30 & S \\
\hline & Vancomycin & $\mathrm{KB}(\mathrm{mm})$ & $\geq 17$ & NA & NA & 22 & S \\
\hline & Erythromycin & $\mathrm{KB}(\mathrm{mm})$ & $\geq 21$ & $16-20$ & $\leq 15$ & 6 & $\mathrm{R}$ \\
\hline & Azithromycin & $\mathrm{KB}(\mathrm{mm})$ & $\geq 18$ & $14-17$ & $\leq 13$ & 6 & $\mathrm{R}$ \\
\hline & Clindamycin & $\mathrm{KB}(\mathrm{mm})$ & $\geq 19$ & $16-18$ & $\leq 15$ & 6 & $\mathrm{R}$ \\
\hline & Clarithromycin & $\mathrm{KB}(\mathrm{mm})$ & $\geq 21$ & $17-20$ & $\leq 16$ & 6 & $\mathrm{R}$ \\
\hline & Tetracycline & $\mathrm{KB}(\mathrm{mm})$ & $\geq 23$ & $19-22$ & $\leq 18$ & 30 & S \\
\hline \multirow{15}{*}{$\begin{array}{l}\text { Staphylococcus } \\
\text { hominis }\end{array}$} & Penicillin & MIC (ug/ml) & $\leq 0.12$ & NA & $\geq 0.25$ & $\geq 0.50$ & $\mathrm{R}$ \\
\hline & Vancomycin & $\mathrm{MIC}(\mathrm{ug} / \mathrm{ml})$ & $\leq 4$ & $8-16$ & $\geq 32$ & 1.0 & S \\
\hline & Gentamicin & $\mathrm{MIC}(\mathrm{ug} / \mathrm{ml})$ & $\leq 4$ & 8 & $\geq 16$ & 1.0 & S \\
\hline & Clindamycin & $\mathrm{MIC}(\mathrm{ug} / \mathrm{ml})$ & $\leq 0.5$ & $1-2$ & $\geq 4$ & $\geq 8.0$ & $\mathrm{R}$ \\
\hline & Tetracycline & MIC (ug/ml) & $\leq 4$ & 8 & $\geq 16$ & $\geq 16.0$ & $\mathrm{R}$ \\
\hline & Ciprofloxacin & MIC (ug/ml) & $\leq 1$ & 2 & $\geq 4$ & 1.0 & S \\
\hline & Levofloxacin & MIC (ug/ml) & $\leq 1$ & 2 & $\geq 4$ & 0.5 & S \\
\hline & Moxifloxacin & MIC (ug/ml) & $\leq 0.5$ & 1 & $\geq 2$ & $\leq 0.25$ & S \\
\hline & Smz-tmp & MIC (ug/ml) & $\leq 2 / 38$ & NA & $\geq 4 / 76$ & 80.0 & $\mathrm{R}$ \\
\hline & Rifampicin & MIC (ug/ml) & $\leq 1$ & 2 & $\geq 4$ & $\leq 0.5$ & S \\
\hline & $\begin{array}{c}\text { Quinupristin/ } \\
\text { dalfopristin }\end{array}$ & MIC (ug/ml) & $\leq 1$ & 2 & $\geq 4$ & 0.5 & S \\
\hline & Linezolid & MIC (ug/ml) & $\leq 4$ & NA & $\geq 8$ & 2.0 & S \\
\hline & Erythromycin & MIC (ug/ml) & $\leq 0.5$ & $1-4$ & $\geq 8$ & $\geq 8.0$ & $\mathrm{R}$ \\
\hline & Oxacillin & MIC (ug/ml) & $\leq 0.25$ & NA & $\geq 0.5$ & $\geq 4.0$ & $\mathrm{R}$ \\
\hline & $\begin{array}{l}\text { Methicillin } \\
\text { resistance }\end{array}$ & & & & & & Positive \\
\hline \multirow[t]{12}{*}{$\begin{array}{c}\text { Pseudomonas } \\
\text { aeruginosa }\end{array}$} & $\begin{array}{l}\text { Piperacillin/ } \\
\text { tazobactam }\end{array}$ & MIC (ug/ml) & $\leq 16 / 4$ & $32 / 4-64 / 4$ & $\geq 128 / 4$ & 16.0 & S \\
\hline & Ceftazidime & MIC (ug/ml) & $\leq 8$ & 16 & $\geq 32$ & 32.0 & R \\
\hline & Imipenenm & MIC (ug/ml) & $\leq 2$ & 4 & $\geq 8$ & $\geq 16.0$ & $\mathrm{R}$ \\
\hline & Meropenem & MIC (ug/ml) & $\leq 2$ & 4 & $\geq 8$ & $\leq 0.25$ & S \\
\hline & Amikacin & MIC (ug/ml) & $\leq 16$ & 32 & $\geq 64$ & $\geq 64.0$ & $\mathrm{R}$ \\
\hline & Ciprofloxacin & MIC (ug/ml) & $\leq 0.5$ & 1 & $\geq 2$ & 0.5 & S \\
\hline & Levofloxacin & $\mathrm{MIC}(\mathrm{ug} / \mathrm{ml})$ & $\leq 1$ & 2 & $\geq 4$ & 1.0 & S \\
\hline & $\begin{array}{l}\text { Cefoperazone/ } \\
\text { sulbactam }\end{array}$ & MIC (ug/ml) & $\leq 16$ & 32 & $\geq 64$ & 32.0 & I \\
\hline & Cefepime & MIC (ug/ml) & $\leq 8$ & 16 & $\geq 32$ & 16.0 & I \\
\hline & Tobramycin & $\mathrm{MIC}(\mathrm{ug} / \mathrm{ml})$ & $\leq 4$ & 8 & $\geq 16$ & 2.0 & S \\
\hline & Polymyxin & MIC (ug/ml) & $\leq 2$ & NA & $\geq 4$ & 2.0 & S \\
\hline & Gentamicin & $\mathrm{KB}(\mathrm{mm})$ & $\geq 15$ & $13-14$ & $\leq 12$ & 17 & S \\
\hline
\end{tabular}

detect tens of thousands of pathogens in a run within $48 \mathrm{~h}$. The pathogen profiles include almost all viruses, bacteria, fungi, and parasites that can infect patients $[12,13]$.The details of materials and methods for mNGS was provided as supplement material (Additional file 1).
Since 2013, professor Charles Chiu first applied mNGS to diagnose the encephalopathy caused by Leptospira infection in a 14-year-old boy [14], this method plays an increasingly important role in pathogen identification. As reported in previous studies, mNGS is more sensitive 
than culture, and is especially useful in the diagnosis of tuberculosis, fungi, viral and anaerobic bacteria infections [15]. This method is particularly important for the diagnosis of serious clinical infections, and intractable cases caused by complex pathogens. In this case, Streptococcus anginosus was cultured from drainage fluid, while other anaerobic pathogens were sterile by culture. However, mNGS retrieved all the pathogens presented in the infected tissues in a short time. The number of total reads obtained from the patient's drainage fluid was $58,184,734$, of which 407,293 reads were of microbial origin. Prevotella oris and Streptococcus anginosus were identified as the top two predominant pathogens, taking up $0.13 \%$ (78,656 reads) and $0.05 \%(28,322$ reads) of the total sequence reads, and $19.31 \%$ and $6.95 \%$ of the total bacterial reads, respectively.

DNM is a serious infectious condition with aggressive and proliferative behavior which could be life-threatening. Prompt diagnosis, early surgical drainage, proper antibiotic therapy, and multidisciplinary collaborations are beneficial. Application of mNGS for pathogen detection makes it possible to detect all the microorganisms quickly, which is important for the adjustment of antibiotics. The wide application of mNGS would contribute to the characterization of pathogen profiles in DNM, which is still poorly characterized, since in almost $40 \%$ of the cases no pathogens can be detected by traditional methods. We believe that, with the progress of technological innovation and the decline of sequencing costs, mNGS will become a routine detection method for pathogenic microorganisms, and a growing number of patients will benefit from it.

\section{Abbreviations}

DNM: Descending necrotizing mediastinitis; mNGS: Metagenomics next generation sequencing; CT: Computed tomographic; AST: Antimicrobial susceptibility testing; VSD: Vacuum Sealing Drainage ${ }_{\text {i }}$ CRP: C reaction protein; PCT: Procalcitonin; BALF: Bronchoalveolar lavage fluid; ME: Mediastinal emphysema; PE: Pleural effusion; IMP: Imipenem, VAN: vancomycin; TNZ: Tinidazole; TZP: Piperacillin/tazobactam; LEV: Levofloxacin; N\%: Percentage of neutrophils; L\%: Percentage of lymphocyte.

\section{Supplementary Information}

The online version contains supplementary material available at https://doi. org/10.1186/s12879-021-06624-4.

Additional file 1. Materials and methods for mNGS.

\section{Acknowledgements}

Not applicable.

\section{Authors' contributions}

DJ was major contributor in drafting the manuscript, CXS, FJJ and PF participated in the diagnosis and treatment of the patient, ZCC and ZQG participated in revising the manuscript critically, YZQ participated in revising the manuscript critically and contributed to conception. All authors read and approved the final manuscript.

\section{Funding}

The work was supported by the corresponding author of this paper. The article-processing and language editing services of this study were supported by the Medicine and Health Science Technology Development Plan of the Shandong Province of China (Grant Number 2016WS0217).

\section{Availability of data and materials}

The datasets analyzed during the current study are not publicly available due to patient privacy concerns but are available from the corresponding author on reasonable request.

\section{Declarations}

\section{Ethics approval and consent to participate}

As this manuscript is a case report of clinical care provided to a patient, and it does not include any of the patient's personal identifiers, ethics approval by the institutional review board was not required.

\section{Consent for publication}

The patient provided written informed consent for the publication of the data.

\section{Competing interests}

The authors declare that they have no competing interests.

\section{Author details}

${ }^{1}$ Department of Clinical Laboratory, Liaocheng People's Hospital, No. 67, Dongchangxi Road, Dongchangfu District, Liaocheng 252000, Shandong, People's Republic of China. ${ }^{2}$ Department Hepatobiliary Surgery, Liaocheng People's Hospital, No. 67, Dongchangxi Road, Dongchangfu District, Liaocheng 252000, Shandong, People's Republic of China. ${ }^{3}$ Department Computed Tomography, Liaocheng People's Hospital, No. 67, Dongchangxi Road, Dongchangfu District, Liaocheng 252000, Shandong, People's Republic of China.

Received: 30 December 2020 Accepted: 27 August 2021

Published online: 03 September 2021

References

1. Estera A. Descending necrotizing mediastinitis. Surg Gynecol Obstetr. 1983. Doi: https://doi.org/10.1016/S1079-2104(00)70121-1.

2. Freeman RK, Vallières E, Verrier ED, Karmy-Jones R, Wood DE. Descending necrotizing mediastinitis: an analysis of the effects of serial surgical debridement on patient mortality. J Thorac Cardiovasc Surg. 2000;119(2):260-7. https://doi.org/10.1016/S0022-5223(00)70181-4.

3. Sarna T, Sengupta T, Miloro M, Kolokythas A. Cervical Necrotizing fasciitis with descending mediastinitis: literature review and case report. J Oral Maxillofac Surg Off J Am Assoc Oral Maxillofac Surg. 2012;70(6):1342-50. https://doi.org/10.1016/j.joms.2011.05.007.

4. Mihos P, Potaris K, Gakidis I, Papadakis D, Rallis G. Management of descending necrotizing mediastinitis. J Oral Maxillofac Surg. 2004;62(8):966-72. https://doi.org/10.1016/j.joms.2003.08.039.

5. Sakamoto H, Aoki T, Kise Y, Watanabe D, Sasaki J. Descending necrotizing mediastinitis due to odontogenic infections. Oral Surg Oral Med Oral Pathol Oral Radiol Endodontol. 2000;89(4):412-9.

6. Cai XY, Zhang WJ, Zhang ZY, Yang C, Zhou LN, Chen ZM. Cervical infection with descending mediastinitis: a review of six cases. Int J Oral Maxillofac Surg. 2006;35(11):1021-5. https://doi.org/10.1016/j.ijom.2006.06.021.

7. Scaglione M, Pinto A, Romano S, Giovine S, Sparano A, Romano L. Determining optimum management of descending necrotizing mediastinitis with CT; experience with 32 cases. Emerg Radiol. 2005;11(5):275-80. https://doi.org/10.1007/s10140-005-0422-3.

8. Marty-Ané C-H, Berthet JP, Alric P, Pegis JD, Rouvière P, Mary H. Management of descending necrotizing mediastinitis: an aggressive 
treatment for an aggressive disease — ScienceDirect. Ann Thorac Surg 1999;68(1):212-7. https://doi.org/10.1016/S0003-4975(99)00453-1.

9. Pa Stene B, Cassir N, Tankel J, Einav S, Fournier PE, Thomas P, et al. Mediastinitis in the intensive care unit patient: a narrative review. Clin Microbiol Infect. 2020;26(1):26-34. https://doi.org/10.1016/..cmi.2019.07.005.

10. Brook I. Current management of upper respiratory tract and head and neck infections. Eur Arch Otorhinolaryngol. 2009;266(3):315-23. https:// doi.org/10.1007/s00405-008-0849-8.

11. Mfe A, et al. Mediastinitis of odontogenic origin. A serious complication with 80 years of history. Br J Oral Maxillofac Surg. 2020. Doi: https://doi. org/10.1016/j.bjoms.2020.09.004.

12. Schlaberg R, Chiu CY, Miller S, Procop GW, Weinstock G, Committee PP, et al. Validation of metagenomic next-generation sequencing tests for universal pathogen detection. Arch Pathol Lab Med. 2017;141(6):776. https://doi.org/10.5858/arpa.2016-0539-RA.

13. Westblade LF, Belkum AV, Grundhoff A, Weinstock GM, Pamer EG, Pallen $\mathrm{MJ}$, et al. Role of clinicogenomics in infectious disease diagnostics and public health microbiology. J Clin Microbiol. 2016;54(7):1686-93. https:// doi.org/10.1128/JCM.02664-15.

14. Seroogy CM, Naccache SN, Somasekar S, Miller S, Biagtan M, Buckley $\mathrm{RH}$, et al. Actionable diagnosis of neuroleptospirosis by next-generation sequencing. N Engl J Med. 2014;370(25):2408-17. https://doi.org/10. 1056/NEJMoa1401268.

15. Miao Q, Ma Y, Wang Q, Pan J, Zhang Y, Jin WT, et al. Microbiological diagnostic performance of metagenomic next-generation sequencing when applied to clinical practice. Clin Infect Dis. 2018;67(S2):231-40. https://doi. org/10.1093/cid/ciy693.

\section{Publisher's Note}

Springer Nature remains neutral with regard to jurisdictional claims in published maps and institutional affiliations.
Ready to submit your research? Choose BMC and benefit from:

- fast, convenient online submission

- thorough peer review by experienced researchers in your field

- rapid publication on acceptance

- support for research data, including large and complex data types

- gold Open Access which fosters wider collaboration and increased citations

- maximum visibility for your research: over $100 \mathrm{M}$ website views per year

At BMC, research is always in progress.

Learn more biomedcentral.com/submissions 